\title{
Parasitic monogenoideans of Sciades herzbergii as bioindicators of environmental quality in amazonian estuarines ecosystems
}

\author{
Parasitos monogenóideos de Sciades herzbergii como bioindicadores da \\ qualidade ambiental de ecossistemas estuarinos amazônicos \\ Kelle de Nazaré Cunha1; Marcus Vinicius Domingues² (D); Lucas Daniel da Silva Cunha; \\ Zélia Maria Pimentel Nunes ${ }^{4}$ (D)
}

\begin{abstract}
'Laboratório de Qualidade de Água, Programa de Pós-graduação em Biologia Ambiental, Instituto de Estudos Costeiros, Universidade Federal do Pará - UFPA, Bragança, PA, Brasil

${ }^{2}$ Laboratório de Sistemática e Coevolução, Programa de Pós-graduação em Biologia Ambiental, Faculdade de Ciências Naturais, Instituto de Estudos Costeiros, Universidade Federal do Pará - UFPA, Bragança, PA, Brasil

${ }^{3}$ Laboratório de Qualidade de Água, Faculdade de Ciências Biológicas, Instituto de Estudos Costeiros, Universidade Federal do Pará UFPA, Bragança, PA, Brasil

${ }^{4}$ Laboratório de Qualidade de Água, Programa de Pós-graduação em Biologia Ambiental, Faculdade de Engenharia de Pesca, Instituto de Estudos Costeiros, Universidade Federal do Pará - UFPA, Bragança, PA, Brasil
\end{abstract}

How to cite: Cunha KN, Domingues MV, Cunha LDS, Nunes ZMP. Parasitic monogenoideans of Sciades herzbergii as bioindicators of environmental quality in amazonian estuarines ecosystems. Braz J Vet Parasito/ 2021; 30(1): e024220. https://doi.org/10.1590/ S1984-29612021013

\begin{abstract}
This study evaluated the use of gill parasitic monogenoideans from Sciades herzbergii (Siluriformes: Ariidae) as bioindicators of environmental quality in Amazonian estuarine ecosystems. Fish were caught in the tidal channels in an impacted area - IA, near the port of São Luís and a reference area - RA, in the Caeté estuary, Bragança. The influence of the capture site and seasonality on parasite abundance, environmental variables and biometric data of hosts were verified. A total of $416 \mathrm{~S}$. herzbergii specimens were analyzed. The weight and total length of fish from the RA were greater than those of the IA. The relative condition factor was influenced by seasonality. A total of 4,265 monogenoidean specimens from the following species were identified: Chauhanellus boegeri, C. susamlimae, C. velum, Calceostomella herzbergii and Dactylogyridae gen. $\mathrm{sp}$. The seasonal mean parasitic abundance of $C$. susamlimae was significantly different, with the highest values recorded during the dry season. The mean abundance of $C$. herzbergii was influenced by seasonality and by the capture site. During the rainy period, the parasite indices in the RA were higher than those of IA. C. herzbergii is a bioindicator sensitive to low water quality, especially in relation to water turbidity in Amazon estuaries.
\end{abstract}

Keywords: Amazon, marine catfish, seasonality, ectoparasites, biomonitoring.

\section{Resumo}

Este estudo avaliou o uso de monogenóideos parasitos das brânquias de Sciades herzbergii (Siluriformes/Ariidae) como bioindicadores de qualidade ambiental em ecossistemas estuarinos amazônicos. Os peixes foram capturados nos canais das marés em uma área impactada - IA, próxima ao porto de São Luís, e uma área de referência RA, no estuário do Caeté, Bragança. A influência do local de captura e sazonalidade na abundância do parasita, variáveis ambientais e dados biométricos dos hospedeiros foram verificados. Um total de 416 espécimes de S. herzbergii foram analisados. O peso e o comprimento total dos peixes da RA foram maiores do que os dos IA. O fator de condição relativo foi influenciado pela sazonalidade. Um total de 4.265 espécimes de monogenóideos das seguintes espécies foram identificados: Chauhanellus boegeri, C. susamlimae, C. velum, Calceostomella herzbergii e Dactylogyridae gen. sp. A abundância parasitária média sazonal de C. susamlimae foi significativamente diferente, 
com os maiores valores registrados durante a estação seca. A abundância média de $C$. herzbergii foi influenciada pela sazonalidade e pelo local de captura. Durante o período chuvoso, os índices parasitários na RA foram superiores aos da IA. C. herzbergii é um bioindicador sensível à baixa qualidade da água, principalmente em relação à turbidez da água em estuários amazônicos.

Palavras-chave: Amazônia, bagre marinho, sazonalidade, ectoparasitos, biomonitoramento.

\section{Introduction}

Coastal aquatic ecosystems represent one of the most vulnerable systems on the planet and face increased anthropogenic stress in terms of pollution, overuse, and environmental degradation (Palm et al., 2011). In 2025, it is estimated that about 2.75 billion people will live less than $90 \mathrm{~km}$ from the coast, taking direct advantage of the resources these ecosystems provide (Palm et al., 2011). In developing countries, these ecosystems are impacted by anthropogenic activities such as urbanization, industrialization, deforestation, lack of sanitation systems, and aquaculture. Port activities are considered as point sources of toxic substances that affect coastal areas (Sousa et al., 2013). Prolonged or chronic exposure to these substances may lead to changes in the biological and ecological structure of the environment, such as changes in species diversity (Bernet et al., 2000) and in eating habits, for example.

The degree of biodiversity is often used as an indicator in the assessment of ecosystem health, and there is a consensus that any disturbance to habitats can affect this diversity (Madi \& Ueta, 2009). Environmental change may also be reflected in the supply and/or quality of resources used by organisms such as shelter, protection, feeding, reproduction, recruitment, and the predation/predator relationship (D'Amelio \& Gerasi, 1997).

Methodologies for the detection, assessment, and monitoring of environmental integrity that use bioindicator species to identify changes in the environmental quality of ecosystems are widely applied (Williams \& Mackenzie, 2003). Fish parasites represent an important part of aquatic biodiversity and are directly affected by biotic and/or abiotic changes in the environment (Dzika \& Wyzlic, 2009-2010). The diversity of the parasite/host relationship is the result of adaptive processes to the parasitic lifestyle in different types of hosts, sites, and environments. Numerically there are more species of parasites than any other taxon on the planet (Mackenzie, 1999; Bayoumy et al., 2015). Environmental changes can lead to significant changes in species diversity, prevalence, intensity of infestation and parasitic abundance (Mackenzie, 1999).

These changes in the parasitic community can be used as early warning of changes in environmental integrity before other groups of aquatic organisms are seriously affected (Mackenzie, 1999). The pattern of parasite abundance and diversity may increase or decrease in the face of environmental disturbance (Mackenzie, 1999). The change in these patterns will depend on the life cycle of the parasites and the nature of the environmental disturbance (Palm et al., 2011). For example, monoxene parasites appear to be better adapted to polluted habitats than heteroxenes (Lafferty, 1997; Dzikowski et al., 2003).

In general, monogenoids are ectoparasites of fish, which have a monoxenous life cycle (when all stages are completed in a single host) and have a significant number of hosts with high parasitic specificity. These parasites can be found in the gill filaments or on the lateral surfaces of the gill arches of the fish, causing injuries (Poulin, 1992; Eiras et al., 2000; Zargar et al., 2012).

Parasitic indices when corroborated by other analyses, such as environmental quality and host condition factor, may increase the accuracy of bioindicators (Madi \& Ueta, 2009; Zargar et al., 2012). The use of an interdisciplinary approach using fish parasites as bioindicators of environmental quality has been reported in several studies (Khan \& Thulin, 1991; Poulin, 1992; Lafferty, 1997; Mackenzie, 1999; Sures, 2004; Marcogliese, 2005; Blanar et al., 2009; Vidal-Martínez et al., 2009). These authors also investigated the effects of pollution and parasitism on fishes, citing the need for research within these parasitic organisms to find suitable bioindicator species.

On the north coast of Brazil, marine catfish, belonging to the Ariidae (Osteichthyes: Siluriformes) and to the Sciades genus, are represented by eight species, including Sciades herzbergii Bloch, 1794. This catfish is found in South America, with distribution from Colombia to the northeast region of Brazil. The species is an estuarine resident inhabiting the turbid and brackish waters of shallow estuaries, and it is abundant in mangrove ecosystems (Espírito Santo \& Isaac, 2005; Marceniuk, 2005). Sciades herzbergii was used as an indicator of environmental quality in a port area of São Marcos Bay, State of Maranhão and was sensitive to trace element contamination in the waters of the bay (Carvalho-Neta \& Abreu-Silva, 2010; Carvalho-Neta et al., 2014). 
Because fish may be more vulnerable to parasites in degraded environmental conditions, our hypothesis is that the parasite indices of specimens of monogenoideans in Sciades herzbergii will reflect the interaction between the loss of environmental quality and the poor nutritional condition of this species in the area impacted by port activity and unplanned urbanization when compared to the parasite indices of this species in a more intact area. Therefore, this work aimed to qualify and quantify the diversity of monogenoidean parasites in S. herzbergii to develop a low-cost tool for evaluating and monitoring the environmental quality of Amazonian estuarine ecosystems using these parasites as bioindicators.

\section{Materials and Methods}

\section{Areas of study and capture of fish}

The selected tidal channels for the collection of water and capture of $S$. herzbergii are located on the north coast of Brazil, in the São Marcos Bay (São Luís, State of Maranhão) and the estuary of the Caeté River (on the Ajuruteua Peninsula, Bragança, State of Pará) (Figure 1). These sites have a macrotidal regime and high rainfall, in addition to being associated with extensive mangrove areas responsible for the primary productivity of this coastal region of the Amazon (Reef et al., 2010; Nascimento et al., 2013).

(a)

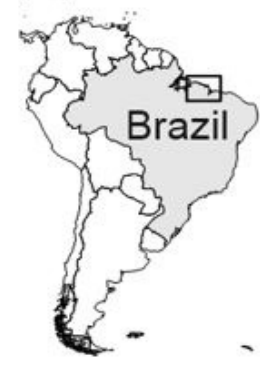

(c)

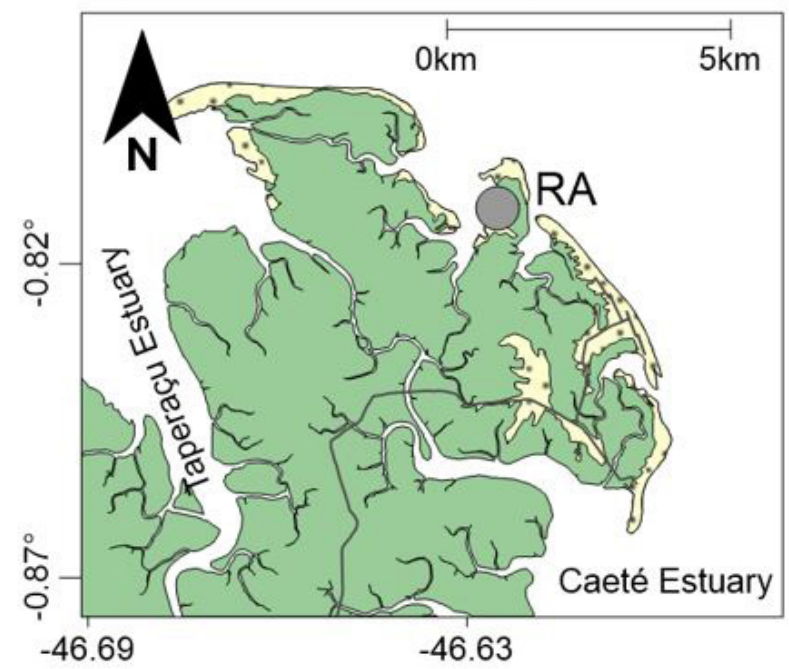

(b)

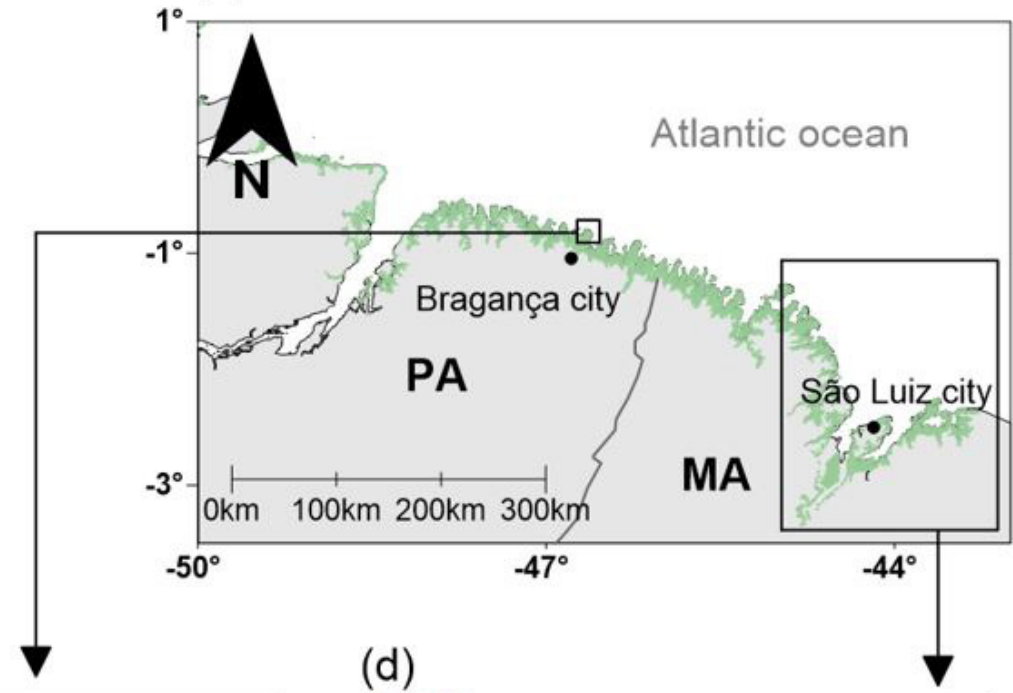

(d)

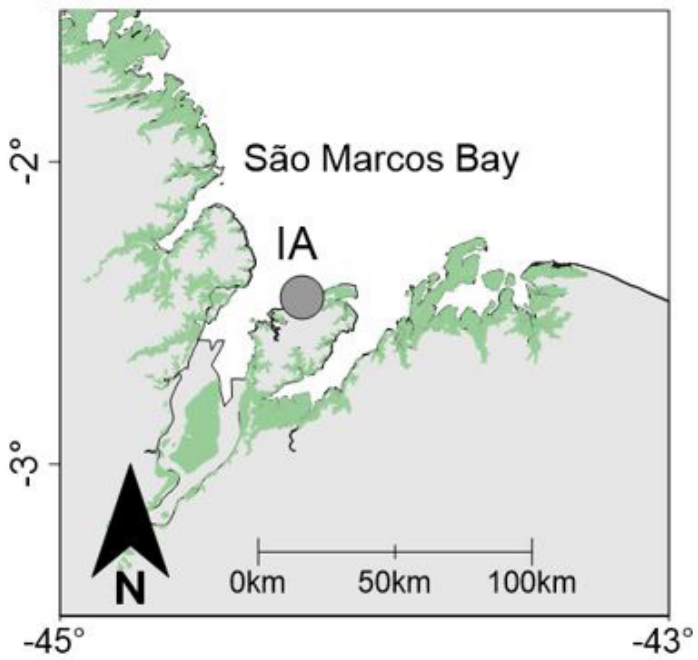

Figure 1. (a) Study area, northern coast of Brazil; (b) Location of the two study sites in the states of Pará and Maranhão; (c) Tidal channels of the Caeté estuarine system, Bragança, Pará, reference area (RA); (d) Tidal channels of São Marcos Bay in São Luís, Maranhão, impacted area (IA). 
In Bragança, the temperature varies between 25 and $30^{\circ} \mathrm{C}$, with average annual rainfall of approximately 2300 to $2800 \mathrm{~mm}$ (Moraes et al., 2005) and a tidal range up to $5 \mathrm{~m}$ (El-Robrini et al., 2006). In the estuarine system of the Caeté River, environmental impacts are mainly associated with urban growth and lack of basic sanitation for local populations (Pereira et al., 2010; Gomes et al., 2011; Monteiro et al., 2016). In the last decades, the lack of sanitation has resulted in a progressive increase in nitrogen and phosphorus levels in Amazon estuaries, which are naturally rich in nutrients (Monteiro et al., 2016).

In the São Marcos Bay, near the Ponta da Madeira Maritime Terminal, the tide variation oscillates between an average of 0.4 and $6.0 \mathrm{~m}$, for low tides and spring tides, respectively. However, tidal height may reach more than $7 \mathrm{~m}$ during equinox tides (UFRJ, 2018). Part of the bay is allocated to the port complex of São Luís composed of the maritime terminals of Alumar, Ponta da Madeira and Itaqui. In 2016 and 2017, these terminals handled approximately 163 and 185 million tons of cargo, respectively (EMAP, 2018). The main commodities were iron ore, bauxite, oil derivatives, pig iron, manganese, and aluminium. The port complex is characterized by its proximity to the Atlantic Ocean, the Panama Canal, extensive depth of the fully-walled access channel, large anchorage areas, and protection from winds and currents (Rima do Porto do Itaqui (EMAP, 2001).

Despite the impacts mentioned above, the tidal channels of the Caeté estuarine system still show low anthropogenic modification and were designated as the reference area (RA). The tidal channels of São Marcos Bay, located between the Alumar and Itaqui maritime terminals along a known pollution gradient, were considered to be the impacted area $(I A)$.

\section{Monitoring water quality in the areas studied}

Twenty surveys were conducted between 2013 and 2015, 10 in the RA site and 10 in the IA site (Table 1). In each of these areas, five campaigns were carried out in the dry season and five in the rainy season (Table 1). During the campaigns, the physicochemical parameters were determined on the water column, with the aid of a multiparameter probe, to measure in situ, temperature, salinity, dissolved oxygen, $\mathrm{pH}$ and turbidity, concomitantly to fish capture. The water samples were collected for analysis of nutrients and chlorophyll, $50 \mathrm{~cm}$ below the surface. The nutrients, ammonia, nitrate and phosphate were analysed according to the methods described by Paranhos (1996) and APHA (2005). Chlorophyll-a was determined by the method described by Nusch (1980).

\section{Host capture and body parameter analysis}

Specimens of S. herzbergii were caught, during high tide, by gillnet fishing efforts, with opening of 20, 25 and $30 \mathrm{~mm}$, length of $100 \mathrm{~m}$ and height of $2 \mathrm{~m}$. The total length $(\mathrm{cm})$ and weight $(\mathrm{g})$ of the fish were measured. The

Table 1. Fish caught number for sampling periods and place of collection of biological material and water in the tidal channels of the reference and impacted areas.

\begin{tabular}{cccc}
\hline \multirow{2}{*}{ Sample $\left(\right.$ month year $\left.{ }^{-1}\right)$} & Seasonal period & Reference area & Impacted area \\
\cline { 3 - 3 } November/2013 & Dry & 11 & 11 \\
March/2014 & Rainy & 15 & 20 \\
May/2014 & Rainy & 32 & 16 \\
October/2014 & Dry & 28 & 26 \\
November/2014 & Dry & 33 & 11 \\
December/2014 & Dry & 26 & 28 \\
January/2015 & Dry & 10 & 22 \\
March/2015 & Rainy & 20 & 23 \\
April/2015 & Rainy & 17 & 25 \\
May/2015 & Rainy & 25 & 17 \\
July/2015 & Dry & & $\mathbf{1 9 9}$ \\
\hline
\end{tabular}


weight/length ratio $\mathrm{W}_{T}=\mathrm{aL}_{\mathrm{T}}^{\mathrm{b}}$ was used, where total weight $\left(\mathrm{W}_{T}\right)$ was the dependent variable and total length $\left(\mathrm{L}_{T}\right)$ was the independent variable, the length and total weight data were log transformed and inserted in scatter plots to obtain the linear regression adjustment using the least squares method. In this way, the regression adjustment equation and its respective linear coefficients $(a, b)$ were obtained, "a" is $(k)$ the interceptor in logarithmic form related to the degree off attening, "b" is the slope related to the type of growth (Ricker, 1975).

The relative condition factor $(k n)$ was calculated using the formula $k n=W_{O} / W_{E}$. This calculation expresses the coefficient between the observed weight $\left(\mathrm{W}_{\mathrm{O}}\right)$ and the theoretically expected weight $\left(\mathrm{W}_{\mathrm{E}}\right)$ for a given length $\left(\mathrm{L}_{T}\right)$ obtained from the relationship $W_{T} / L_{T}$. The kn was calculated to identify the difference in body condition of the catfish caught in the RA and in the IA (Le Cren,1951).

\section{Collection and identification of parasites}

After the biometric data were measured, the holes and skin surface of the catfish were macroscopically observed for ectoparasites. When found, the parasites were removed with tweezers and stored in micro tubes with $70 \%$ alcohol solution or $5 \%$ aqueous formaldehyde solution. After this procedure, the gill arches were removed, placed in a labelled container containing water heated to between 60 and $70^{\circ} \mathrm{C}$, and shaken vigorously in order to avoid entanglement of the parasite specimens. The parasites shared by each sample unity (fish), were fixed with the addition of $5 \%$ aqueous formaldehyde solution to the water containing the samples of gills from host (Justine et al., 2012).

The gill arches were examined in the laboratory. The parasites were counted in totum and separated by morphotypes using a stereoscopic microscope. The specimens were conditioned in microtubes containing 5\% aqueous formaldehyde solution, following the methodologies of Thatcher (1981) and Justine et al. (2012). The identification of monogenoids was made by making Hoyer's mounted slides for visualization of sclerotized structures, as described by Zambrano et al. (2004), Domingues \& Fehlauer (2006) and Domingues et al. (2016).

After qualitative and quantitative analysis, parasitic indices such as prevalence, mean intensity and mean abundance were calculated according to Bush et al. (1997).

\section{Statistical analysis}

Fischer's test was used to verify the influence of the capture area (RA vs. IA) on the parasite indices per species of S. herzbergii monogenoideans. Data the abundance, environmental variables and body parameters of the host were tested for normality. The environmental data were standardized, and the abundance was logarithmically transformed $(\log x+1)$.

Factorial ANOVA was used to verify whether the abundance of the parasites was influenced by the collection site (RA vs. IA) and the season (dry vs. rainy). For this purpose, the abundance data associated with the environmental variables of water quality were used, as well as the biometric data of the hosts, including kn calculated separately for the two environments. The Tukey test was used to detect the source of variation when the differences tested by ANOVA were significant. These analyses were performed using the Statistica version 10.0 (Statsoft, Tulsa, OK, USA).

A redundancy analysis (RDA) was performed to verify which environmental variables were correlated with the abundance of the parasite species recorded and whether seasonality had an effect. The parasite abundance data were transformed using Hellinger transformation (Legendre \& Gallagher, 2001) and the environmental data were standardized. This analysis was performed using $R$ version 3.4.1.

\section{Results}

\section{Environmental characterization of tidal channels}

The environmental characteristics of the $S$. herzbergii capture sites, in terms of physical, chemical and biological water variables, rainfall and wind intensity, are described in Table 2 . These sites differed in relation to turbidity $(F=23.375 ; p<0.001)$ and wind intensity $(F=995.758 ; p<0.001)$ which were significantly higher in the $I A$ site, with values of $254.95 \pm 143.26$ Nephelometric Turbidity Unit (NTU) and $2.16 \pm 0.65 \mathrm{~m}^{-1} \mathrm{~s}^{-1}$, respectively. The value of chlorophyll-a at RA $\left(9.01 \pm 5.26 \mu . \mathrm{L}^{-1}\right)$ was significantly greater than that of IA $(F=25.616 ; \mathrm{p}<0.001)$. 
Table 2. Mean values and/or concentrations and standard deviation of environmental variables during the dry and rainy seasons in the reference area and impacted area. Different letters represent statistically significant values $(p<0.05)$.

\begin{tabular}{|c|c|c|c|c|}
\hline \multirow{2}{*}{ VARIABLE } & \multicolumn{2}{|c|}{ REFERENCE AREA } & \multicolumn{2}{|c|}{ IMPACTED AREA } \\
\hline & DRY & RAINY & DRY & RAINY \\
\hline Temperature $\left({ }^{\circ} \mathrm{C}\right)$ & $29.04 \pm 1.03^{a}$ & $28.82 \pm 0.82^{a}$ & $28.42 \pm 0.41^{a}$ & $29.00 \pm 0.56^{a}$ \\
\hline Salinity & $35.67 \pm 2.88^{a}$ & $20.31 \pm 5.98^{b}$ & $31.12 \pm 3.71^{c}$ & $28.66 \pm 4.21^{c}$ \\
\hline $\mathrm{pH}$ & $7.92 \pm 0.30^{\mathrm{a}}$ & $7.84 \pm 0.68^{\mathrm{a}}$ & $8.21 \pm 0.44^{a}$ & $8.06 \pm 0.85^{a}$ \\
\hline Turbidity (NTU) & $43.53 \pm 18.93^{a}$ & $30.24 \pm 12.78^{a}$ & $244.73 \pm 183.19^{b}$ & $133.84 \pm 130.16^{a}$ \\
\hline $\begin{array}{l}\text { Dissolved oxygen } \\
\quad\left(\mathrm{mg} \mathrm{L}^{-1}\right)\end{array}$ & $5.57 \pm 1.25^{\mathrm{a}}$ & $6.83 \pm 0.96^{a}$ & $6.37 \pm 0.96^{a}$ & $7.10 \pm 1.25^{\mathrm{a}}$ \\
\hline Ammonia $(\mu \mathrm{M})$ & $7.92 \pm 5.46^{\mathrm{a}}$ & $11.83 \pm 15.20^{a}$ & $6.06 \pm 4.57^{a}$ & $8.32 \pm 3.44^{\mathrm{a}}$ \\
\hline Phosphate $(\mu \mathrm{M})$ & $1.14 \pm 0.58^{\mathrm{a}}$ & $1.02 \pm 0.43^{a}$ & $1.75 \pm 1.80^{\mathrm{a}}$ & $1.40 \pm 1.03^{a}$ \\
\hline Nitrite $(\mu \mathrm{M})$ & $0.06 \pm 0.04^{a}$ & $0.09 \pm 0.08^{a}$ & $0.06 \pm 0.05^{\mathrm{a}}$ & $0.22 \pm 0.20^{\mathrm{b}}$ \\
\hline Chlorophyll- $a\left(\mu \mathrm{L} \mathrm{L}^{-1}\right)$ & $10.19 \pm 5.13^{a}$ & $6.15 \pm 1.71^{c}$ & $5.52 \pm 2.38^{b}$ & $2.72 \pm 1.21^{\mathrm{b}}$ \\
\hline Rainfall (mm) & $3.05 \pm 4.23^{a}$ & $343.42 \pm 101.23^{b}$ & $24.58 \pm 28.50^{a}$ & $428.52 \pm 225.08^{b}$ \\
\hline Wind $\left(m \cdot s^{-1}\right)$ & $0.98 \pm 0.02^{\mathrm{a}}$ & $0.49 \pm 0.09^{b}$ & $2.77 \pm 0.21^{c}$ & $1.53 \pm 0.21^{d}$ \\
\hline
\end{tabular}

In the RA site the environmental variables, salinity, chlorophyll-a e wind intensity, were influenced by seasonality during the dry season, when significantly higher values of salinity $(F=53.885 ; p<0.001)$, chlorophyll- $a$ $(F=18.360 ; p=0.005)$ and wind intensity $(F=69.514 ; p<0.001)$ were recorded. In contrast, the lowest mean salinity values were observed at $20.31 \pm 5.98$ in the rainy season. This area was characterized by low turbidity and low nitrite concentration (Table 2).

In the IA site was characterized by the highest values of wind intensity $(F=69.515 ; p<0.0001)$ and turbidity $(F=23.375 ; p<0.0001)$ that were recorded during the dry season. In the rainy season, the highest nitrite concentration $(\mathrm{F}=4.163 ; \mathrm{p}=0.026)$ was registered (Table 2$)$.

\section{Host - Sciades herzbergii}

A total of 416 specimens of $S$. herzbergii were captured, 217 specimens from the RA site and 199 specimens from the IA site. Table 3 shows that the RA fish had a higher weight $(208.35 \pm 147.78 \mathrm{~g})$ and total length $(28.283 \pm 6.283 \mathrm{~cm})$ than those at IA ( $F=63.948 ; p<0.0001$ and $F=63.001 ; p<0.0001$, respectively). These values were highly significant. Both weight and total length were influenced by seasonality and their highest values $(195.405 \pm 140.999 \mathrm{~g}$ and $27.846 \pm 5.635 \mathrm{~cm}$ ) were recorded in the dry season ( $F=17.983 ; p<0.0001$ and $F=23.735 ; p<0.0001$, respectively).

In the RA site, the host kn was also influenced by seasonality $(F=7.33 ; p=0.007)$. During the dry season, the catfish were in better condition ( $k n=1.053 \pm 0.135)$ compared with the rainy season ( $k n=0.991 \pm 0.126)$ (Table 3$)$. In the IA site, the condition of the catfish was not influenced by seasonality.

\section{Parasitic indexes}

Of the total hosts analysed, 331 were parasitized by at least one species of monogenoid, totalling $79.57 \%$ of the prevalence. A total of 4,265 monogenoidean parasites were found. This total was made up of 2,501 specimens (58.5\%) of Chauhanellus boegeri; 1,619 specimens (37.87\%) of C. susamlimae; 107 specimens (2.5\%) of Calceostomella herzbergii Zambrano, Dezón and León, 2004; and 18 specimens (0.4\%) of C. velum Domingues, Soares and Watanabe, 2016. Twenty specimens (0.5\%) of Dactylogyridae gen. sp. were recorded, exclusively in the IA site (Table 4). Fish caught in the impacted area showed excessive mucus production, as well as visible lesions both in the gills and mucosa. These alterations occurred concomitantly with the presence of the parasitic crustaceans Copepoda and Isopoda, from the Gnathidae family, mainly in the rainy season.

Parasitic infestation rates in S. herzbergii had similar distribution patterns for C. boegeri, C. susamlimae and C. velum in the study areas. The prevalence of C. boegeri was higher than C. susamlimae, C. herzbergii and C. velum 
Table 3. Mean values and standard deviation of body parameters of Sciades herzbergii catfish in the reference area and in the impacted area, in the dry and rainy seasons. Different letters represent statistically significant values $(p<0.05)$.

\begin{tabular}{|c|c|c|c|c|c|c|}
\hline \multirow{2}{*}{$\begin{array}{c}\text { Body } \\
\text { parameters }\end{array}$} & \multicolumn{3}{|c|}{ REFERENCE AREA $(n=217)$} & \multicolumn{3}{|c|}{ IMPACTED AREA $(n=199)$} \\
\hline & General & Dry & Rainy & General & Dry & Rainy \\
\hline $\mathrm{W}_{\mathrm{T}}(\mathrm{g})$ & $208.35 \pm 147.78^{a}$ & $251.87 \pm 155.26^{c}$ & $169.03 \pm 129.23^{d}$ & $114.04 \pm 89.34^{b}$ & $124.48 \pm 75.22^{\mathrm{e}}$ & $106.73 \pm 97.67^{e}$ \\
\hline $\mathrm{L}_{\mathrm{T}}(\mathrm{cm})$ & $28.28 \pm 6.28^{a}$ & $30.20 \pm 5.21^{c}$ & $26.55 \pm 6.67^{d}$ & $23.93 \pm 4.86^{b}$ & $24.89 \pm 4.69^{e}$ & $23.25 \pm 4.89^{e}$ \\
\hline $\mathrm{kn}$ & $1.020 \pm 0.133$ & $1.053 \pm 0.135^{\mathrm{a}}$ & $0.991 \pm 0.126^{b}$ & $1.017 \pm 0.149$ & $1.024 \pm 0.144$ & $1.012 \pm 0.153$ \\
\hline
\end{tabular}

$\mathrm{W}_{\mathrm{T}}=$ Total wheight; $\mathrm{L}_{\mathrm{T}}=$ Total length; $\mathrm{kn}=$ Condition factor; $\mathrm{n}=$ sample number.

Table 4. Monogenoidean infestation indices in the gills of Sciades herzbergii caught in tidal channels of the reference area (RA, Caeté River estuary in Bragança, state of Pará), and the impacted area (IA, São Marcos Bay in São Luís, state of Maranhão). $\mathrm{P}(\%)=$ prevalence, $\mathrm{MI}=$ mean intensity and $\mathrm{MA}=$ mean abundance.

\begin{tabular}{|c|c|c|c|c|c|c|}
\hline \multirow{2}{*}{ SPECIES PARASITES } & \multicolumn{3}{|c|}{ RA } & \multicolumn{3}{|c|}{ IA } \\
\hline & $\mathrm{P}(\%)$ & MI & MA & P (\%) & MI & MA \\
\hline Chauhanellus boegeri & 70.97 & 6.61 & 6.61 & 75.38 & 7.11 & 5.36 \\
\hline Chauhanellus susamlimae & 54.84 & 7.10 & 3.89 & 65.33 & 5.95 & 3.89 \\
\hline Calceostomella herzbergii & 19.35 & 1.93 & 0.37 & 13.07 & 1.18 & 0.13 \\
\hline Chauhanellus velum & 3.69 & 1.38 & 0.05 & 3.52 & 1.75 & 0.04 \\
\hline Dactylogyridae gen. sp. & 0.00 & 0.00 & 0.00 & 10.05 & 6.67 & 0.10 \\
\hline
\end{tabular}

Table 5. Summary of the univariate analysis using Fischer's test to verify the influence of the capture area and monogenoidean species on the parasite indices of Sciades herzbergii.

\begin{tabular}{ccccc}
\hline DEPENDENT VARIABLE & FACTORS & F & p & GEI \\
\hline Prevalence (\%) & Area & 0.03 & $>0.05$ & IA $\geq \mathrm{RA}$ \\
Species & 79.0 & $<\mathbf{0 . 0 1}$ & $\mathrm{CB}>\mathrm{CS}>\mathrm{CH}>\mathrm{CV} \geq \mathrm{DA}$ \\
Mean intensity & Area & 0.34 & $>0.05$ & $\mathrm{IA}>\mathrm{RA}$ \\
& Species & 2.88 & $>0.05$ & $\mathrm{CB}>\mathrm{CS}>\mathrm{DA}>\mathrm{CV}=\mathrm{CH}$ \\
Mean abundance & Area & 0.02 & $>0.05$ & $\mathrm{RA} \geq \mathrm{IA}$ \\
& Species & 91.5 & $<\mathbf{0 . 0 1}$ & $\mathrm{CB}>\mathrm{CS}>\mathrm{CH} \geq \mathrm{CV}=\mathrm{DA}$ \\
\hline
\end{tabular}

$\mathrm{IA}=$ Impacted area; $\mathrm{RA}=$ Reference area; $\mathrm{CB}=$ Chauhanellus boegeri; $\mathrm{CS}=\mathrm{C}$. susamlimae; $\mathrm{CV}=\mathrm{C}$. velum; $\mathrm{CH}=$ Calceostomella herzbergii; $\mathrm{DA}=$ Dactylogyridae gen. $\mathrm{sp} ; \mathrm{F}=$ Fisher test; $\mathrm{p}=$ probability; $\mathrm{GEI}=$ graphic and/or statistical interpretation .

in the sequence. The mean intensity of parasites did not differ statistically ( $F=2.88 ; p>0.05)$ among the species. However, the mean abundance of $C$. boegeri was higher than $C$. susamlimae, which in turn was higher than C. herzbergii, C. velum and Dactylogyridae gen. sp. (Table 5).

The average parasitic abundance of $C$. boegeri was influenced by the interaction between the capture site and seasonality (area*season). In the RA site, the highest abundance of this parasite was recorded in the dry season and the lowest abundance in the rainy season (Table 6). The mean abundance of $C$. susamlimae was higher in the dry season $(p<0.05)$. However, there was an influence of the interaction between the capture site and seasonality and, in the rainy season, the abundance of $C$. susamlimae was higher in the IA site. Calceostomella herzbergii was more abundant in the rainy season in the RA site. C. velum and Dactylogyridae gen. sp. were less abundant during the study and were not influenced by the capture site or the season. During the dry season, the kn reflected a higher value than during the rainy season (Table 6).

\section{Environment and parasites}

The RDA 1 and RDA 2 axes of the redundancy analysis explained 98.2\% of the data variation (Figure 2). The environmental variables that most contributed were precipitation, salinity, nitrite, dissolved oxygen, $\mathrm{pH}$, 
Table 6. Summary of ANOVA results for the influence of environment and seasonality (dry vs. rainy season) in relation to the abundance of monogenoidean parasites and the condition factor $(\mathrm{kn})$ of the host Sciades herzbergii caught in the tidal channels of the reference area (RA, Caeté River Estuary in Bragança, state of Pará), and the impacted area (IA, São Marcos Bay in São Luís, state of Maranhão).

\begin{tabular}{|c|c|c|c|c|c|}
\hline BIOLOGICAL VARIABLE & $\mathbf{n}$ & FACTORS & $\mathbf{F}$ & $\mathbf{P}$ & GEI \\
\hline \multirow[t]{3}{*}{ Chauhanellus boegeri } & 2.501 & Season & 2.626 & 0.106 & \\
\hline & & Area & 0.447 & 0.504 & \\
\hline & & Season*Area & 10.318 & 0.002 & RAD $>$ RAR \\
\hline \multirow[t]{3}{*}{ Chauhanellus susamlimae } & 1.619 & Season & 44.183 & 0.000 & Dry>Rainy \\
\hline & & Area & 1.648 & 0.200 & \\
\hline & & Season*Area & 11.833 & 0.001 & IAR $>$ RAR \\
\hline \multirow[t]{3}{*}{ Chauhanellus velum } & 18 & Season & 0.300 & 0.584 & \\
\hline & & Area & 0.796 & 0.373 & \\
\hline & & Season*Area & 0.334 & 0.564 & \\
\hline \multirow[t]{3}{*}{ Calceostomella herzbergii } & 107 & Season & 10.055 & 0.002 & Rainy $>$ Dry \\
\hline & & Area & 10.123 & 0.002 & $\mathrm{RA}>\mathrm{IA}$ \\
\hline & & Season*Area & 0.517 & 0.473 & \\
\hline \multirow[t]{3}{*}{ Dactylogiridae gen. sp. } & 20 & Season & 0.040 & 0.841 & \\
\hline & & Area & 3.100 & 0.079 & \\
\hline & & Season*Area & 0.040 & 0.841 & \\
\hline \multirow[t]{3}{*}{$\mathrm{kn}$} & 416 & Season & 6.177 & 0.013 & Dry>Rainy \\
\hline & & Area & 0.013 & 0.909 & \\
\hline & & Season*Area & 2.470 & 0.117 & \\
\hline
\end{tabular}

$\mathrm{RAD}=$ Reference area dry; RAR - Reference area rainy; IAR= Impacted area rainy; F = Fisher test; $\mathrm{p}=$ probability; GEI = graphic and/or statistical interpretation; $\mathrm{n}=$ sample number.

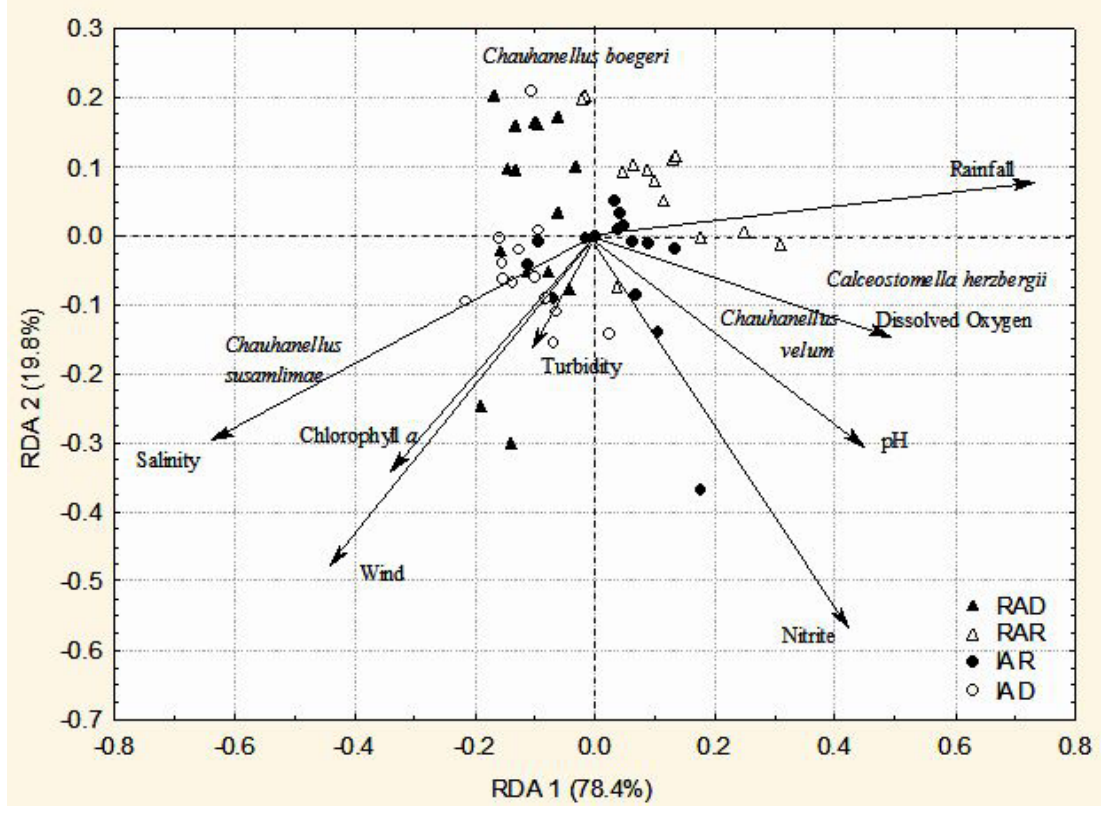

Figure 2. Redundancy analysis of the numerical abundance matrices of monogenoid parasites of Sciades herzbergii gills and environmental variables at capture sites. RAD - reference area in the dry season, RAR - reference area in the rainy season, $I A D$ - impacted area in the dry season, IAR - impacted area in the rainy season. ANOVA $(F=7.203 ; p=0.001)$. 
Table 7. Redundancy analysis correlation matrix between environmental variables and the abundance of monogenoidean parasites of Sciades herzbergii (RDA 1 and RDA2= canonical ordination axis; $p=$ probability).

\begin{tabular}{|c|c|c|}
\hline VARIABLES & RDA 1 & RDA 2 \\
\hline Salinity & -0.642 & -0.295 \\
\hline Turbdity & -0.105 & -0.167 \\
\hline Chlorophyll-a & -0.338 & -0.343 \\
\hline Rainfall & 0.732 & 0.079 \\
\hline Wind & -0.440 & -0.479 \\
\hline $\mathrm{pH}$ & 0.447 & -0.304 \\
\hline Dissolved Oxygen & 0.493 & -0.144 \\
\hline Nitrite & 0.427 & -0.571 \\
\hline Chauhanellus susamlimae & -0.447 & -0.214 \\
\hline Chauhanellus boegeri & -0.083 & 0.265 \\
\hline Chauhanellus velum & 0.336 & -0.120 \\
\hline Calceostomella herzbergii & 0.466 & -0.073 \\
\hline Dactylogiridae gen. sp. & -0.003 & -0.016 \\
\hline Eigenvalue & 0.007 & 0.002 \\
\hline Proportion Explained & 0.784 & 0.198 \\
\hline Cumulative Proportion & 0.784 & 0.982 \\
\hline $\mathrm{p}$ & 0.001 & \\
\hline
\end{tabular}

and wind intensity. The RDA 1 (78.4\%) showed the correlation between the dissolved oxygen concentration and rainfall with the presence of the parasite $C$. herzbergii. This condition of well oxygenated water predominated in the RA site during the rainy season. In contrast, the abundance of $C$. susamlimae was correlated with the higher values of salinity, chlorophyll-a and wind intensity, and these conditions prevailed during the dry season (Figure 2, Table 2).

On the RDA 2 axis (19.8\%), the abundance of $C$. boegeri was associated with a lower concentration of nitrite and a lower wind intensity which occurred mainly in the RA site during the dry season as opposed to the prevailing conditions in the IA site during the rainy season (Figure 2, Table 7).

\section{Discussion}

The environmental variables of the tidal channels differed with respect to turbidity, wind intensity and phytoplankton biomass (expressed by chlorophyll-a). The tidal channels of São Marcos Bay (IA) suffer intense anthropogenic pressure from port activities. The high turbidity $(244.733 \pm 183.192$ NTU) recorded during the dry season was attributed to the frequent dredging carried out in the navigation channel of São Marcos Bay and the increase in wind intensity in this season, which intensifies the resuspension of the predominantly mud/clay sediment in the bay. The better environmental quality of the tidal channels in the RA site can be characterized by lower turbidity and higher chlorophyll-a concentration. In addition, the tidal channels of the Caeté estuarine system (RA) are influenced by seasonality. In the rainy season, low salinity values, nitrite concentrations and good oxygenation conditions were recorded. In these channels, estuarine conditions predominated while in the tidal channels of São Marcos Bay marine conditions prevailed.

The anthropogenic impacts on the tidal channels of São Marcos Bay are likely to have influenced the total weight and total length of hosts, which were smaller in these channels when compared to the body parameters of the fish collected in the RA site. This bay continuously receives industrial waste from the port and its waters show concentrations of trace elements above the limits allowed by Brazilian legislation (Carvalho-Neta \& 
Abreu-Silva, 2013, Carvalho-Neta et al., 2014). Sousa et al. (2013) found a similar pattern for S. herzbergii caught in São Marcos Bay in relation to another less impacted area, Caranguejos Island, State of Maranhão. This trend was correlated with altered physiological conditions such as metabolic disorders and cellular damage to the gills of fish due to domestic and industrial contaminants from untreated sewage from the city of São Luís and port activity in the IA site, respectively (Carvalho-Neta \& Abreu-Silva, 2013).

The $\mathrm{kn}$ of $\mathrm{S}$. herzbergii suggested that the parasitic infestations by monogenoids showed low pathogenicity on the well-being of the host. Other studies have reported that parasites with low pathogenicity can occur in high abundance in the host without negatively influencing their condition (Lizama et al., 2006; Moreira et al., 2010). Furthermore, it was verified that the kn of the marine catfish, Netuma barba (Lacepède, 1803) and Sciades proops (Valenciennes, 1840), was not influenced by parasite infestation from several taxa, including monogenoids (Tavares \& Luque, 2004; Carvalho et al., 2015).

The higher prevalence and parasitic abundance of $C$. boegeri, especially during the dry season in the RA site, may be related to the body parameters of the hosts $(k n=1.053)$ in the tidal channels of the Caeté River estuarine system. The total length and weight of $S$. herzbergii was greater in the RA site, providing a larger body surface of the host for anchorage and fixation of parasites. Sasal et al. (1999) noted that the richness of monogenoids parasites was positively correlated with host body size and that specific monogenoids were found in larger fish.

The four monogenoidean species identified parasitizing S. herzbergii in tidal channels, C. boegeri, C. susamlimae, C. velum and C. herzbergii, have been reported described for this host, in addition to parasitizing other Ariidae catfish (Zambrano et al., 2004; Domingues \& Fehlauer, 2006; Domingues et al., 2016). For example, C. susamlimae has been reported on Sciades passany (Valenciennes, 1840); and C. velum on Sciades couma (Valenciennes, 1840) and S. passany (Domingues et al., 2016).

The parasitic abundance of $C$. susamlimae was influenced by the prevailing conditions during the dry season when the highest values of salinity, wind intensity and chlorophyll-a were recorded. It is worth noting that in the tidal channels of Caeté (RA), during the rainy season, when salinity was lower, the parasitic abundance of this species was also lower. Thus, it can be inferred that this species preferred marine conditions over estuarine conditions. That is, we can consider it a species more tolerant to higher water salinity. This fact is corroborated by the reported of Kritsky et al. (2010) studying Monogenoidea (Diplectanidae) of three species of Centropomus in the coast of Florida, where they observed that salinity was a determining factor in the distribution of the monogenoidean community.

Among the species of parasites identified in this research, only C. herzbergii showed a significant difference in abundance between the areas and was influenced by seasonality. Probably, the lower abundance of this parasite in S. herzbergii caught in the tidal channels of São Marcos Bay can be related to the poor conditions of the water quality and also by the presence of trace elements, which are related to a decrease in monogenoidean numbers. Corroborating these results, it was verified that the effects of different pollutants resulted in a lower prevalence of monogenoids in the mullet community Liza aurata (Risso, 1810) and L. ramada (Risso, 1827) (Mugilidae) on the Mediterranean coast in an area impacted by port activity (Dzikowski et al., 2003). Carvalho-Neta et al. (2014) recorded high concentrations of aluminium, lead and cadmium in the surface waters and sediment of the port region of São Marcos Bay. Using quantitative methods of stress assessment and environmental contamination, Blanar et al. (2009) obtained similar results in monogenoid populations that had reduced abundance associated with the presence of trace elements in water, suggesting they could act as indicators of metal pollution.

Taking into account the above, the hypothesis that changes in the parasitic indices of monogenoids in S. herzbergii may result from antagonistic interactions between the loss of environmental quality and the low body condition of this species was reinforced. The effect of water quality and seasonality on the mean abundance and occurrence of monogenoidean parasites in S. herzbergii, reflected in the body parameters and the condition factor of hosts, allows the use of the parasite species $C$. herzbergii as an indicator of environmental quality of estuarine ecosystems with low anthropogenic influence on the Brazilian Amazon coast. Due to results observed with this monogenoid there is a strong indication that it this bioindicator parasite showed to be sensitive to changes in water quality in the tidal channels in the IA, located near the port area of São Marcos Bay-MA, mainly due to increased turbidity.

The high turbidity in the tidal channels of São Marcos Bay with a maximum value of 300 NTU caused by frequent dredging in the navigation channel and associated with the action of strong winds in the resuspension of sediment

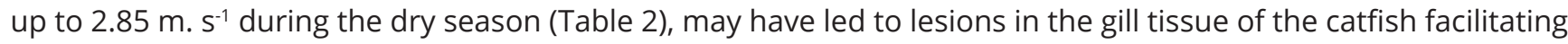
the fixation of parasites. A similar fact was reported by Madi \& Ueta (2009) when they compared two areas with different levels of eutrophication and high turbidity, found that suspended material in the water or pollution caused severe lesions in the fish gills and increased their susceptibility to monogenoidean parasites. These authors also 
found that the changes in parasitism between the two areas were differentiated, where the water quality was lower, the pollutants acted as a stressor causing physical and physiological changes deleterious to fish immunity leaving them more vulnerable to monogenoidean infestations.

The mean abundance of the Calceostomella herzbergii of the marine catfish S. herzbergii was correlated to the environmental variables of water quality in estuarine environments in the Amazonian coast and proved to be an effective tool to indicate environmental quality. Sensitive indicators in short-term studies generally respond relatively quickly and in the same period of time to possible stressors such as increased turbidity in estuaries. Thus, it can be concluded that the $C$. herzbergii parasite can be used as a bioindicator because it is sensitive to decreasing water quality, especially in relation to high turbidity in the Amazon estuaries. It is important to note that the Amazon coastal zone has mangrove areas that provide a high potential value for this zone in economic, social and environmental terms. However, this potential has been neglected by the local government. The results of this research can be used as a low-cost tool in the evaluation and monitoring of the environmental quality of Amazonian estuarine ecosystems using the parasites as bioindicators. In addition, these results are relevant for giving birth to initial, and so far unique, information regarding the understanding of the ecology of these specific parasite species. Since these are recently discovered and described species.

\section{Acknowledgements}

The authors are grateful for the financial support of the research project ICAAF 02/2012 of Fundação de Amparo a Pesquisa do Estado do Pará - FAPESPA and VALE. To the Coordenação de Aperfeiçoamento de Pessoal de Nivel Superior (CAPES) and the Program de Pós-Graduação em Biologia Ambiental, Universidade Federal do Pará (UFPA) for granting the doctoral scholarship, for the use of the infrastructure of laboratories and equipments of the Instituto de Estudos Costeiros da UFPA Campus Bragança. To the Ministry of the Environment for granting license No. 28969-4 for the collection and capture of biological material for scientific activities. For the support of Jonathan Alves de Souza and Leonardo Fernandes da Paixão on field trips and Geusivam Barbosa Soares for helping with the correct identification of the monogenoideans parasites.

\section{References}

American Public Helth Association - APHA. Standard methods for examination of water and wastewater. 21st ed. Washington: APHA/AWWA/WEF; 2005

Bayoumy EM, Abou-el-Dobal SKA, Hassanain MA. Assessment of heavy metal pollution and fish parasites as biological indicators at Arabian Gulf off Dammam Coast, Saudi Arabia. Int J Zool Res 2015; 11(5): 198-206. http://dx.doi.org/10.3923/ijzr.2015.198.206.

Bernet D, Schmidt-Posthaus H, Wahli T, Burkhardt-Holm P. Effects of wastewater on fish health: an integrated approach to biomarker responses in brown trout (Salmo trutta L.). J Aquat Ecosyst Stress Recovery 2000; 8(2): 143-151. http://dx.doi. org/10.1023/A:1011481632510.

Blanar CA, Munkittrick KR, Houlahan J, MacLatchy DL, Marcogliese DJ. Pollution and parasitism in aquatic animals: a meta-analysis of effect size. Aquat Toxicol 2009; 93(1): 18-28. http://dx.doi.org/10.1016/j.aquatox.2009.03.002. PMid:19349083.

Bush AO, Lafferty KD, Lotz JM, Shostak AW. Parasitology meets ecology on its own terms: margolis et al. revisited. J Parasitol 1997; 83(4): 575-583. http://dx.doi.org/10.2307/3284227. PMid:9267395.

Carvalho RP, Takemoto RM, Melo CM, Jeraldo VL, Madi RR. Structure of the parasite infracommunity of Sciades proops from the Japaratuba River Estuary, Sergipe, Brazil. Braz J Biol 2015; 75(4): 906-913. http://dx.doi.org/10.1590/1519-6984.02514. PMid:26675906.

Carvalho-Neta RNF, Abreu-Silva AL. Sciades herzbergii oxidative stress biomarkers: an in situ study of estuarine ecosystem (São Marcos' Bay, Maranhão, Brazil). Braz J Oceanogr 2010; 58(4): 11-17. http://dx.doi.org/10.1590/S1679-87592010000800003.

Carvalho-Neta RNF, Abreu-Silva AL. Glutathione S-Transferase as biomarker in Sciades herzbergii (Siluriformes: Ariidae) for environmental monitoring: the case study of São Marcos Bay, Maranhão, Brazil. Lat Am J Aquat Res 2013; 41(2): 217-225. http:// dx.doi.org/10.3856/vol41-issue2-fulltext-2.

Carvalho-Neta RNF, Sousa DBP, Almeida ZS, Santos DMS, Tchaicka L. A histopathological and biometric comparison between catfish (Pisces, Ariidae) from a harbor and a protected area, Brazil. Aquat Biosyst 2014; 10(1): 12. http://dx.doi.org/10.1186/ s12999-014-0012-5. PMid:25535566. 
D’Amelio S, Gerasi L. Evaluation of environmental deterioration by analysing fish parasite biodiversity and community structure. Parassitologia 1997; 39(3): 237-241. PMid:9802073.

Domingues MV, Fehlauer KH. New species of Chauhanellus (Monogenoidea, Platyhelminthes) from the gills of Southern Atlantic marine catfishes (Siluriformes, Ariidae) on the Neotropical Region. Zootaxa 2006; 1365(1): 61-68. http://dx.doi.org/10.11646/ zootaxa.1365.1.5.

Domingues MV, Soares GR, Watanabe A. Monogenoidea (Polyonchoinea: Dactylogyridae) parasitizing the gills of marine catfish (Siluriformes: Ariidae) inhabiting the Atlantic Amazon Coast of Brazil. Zootaxa 2016; 4127(2): 301-326. http://dx.doi.org/10.11646/ zootaxa.4127.2.4. PMid:27395625.

Dzika E, Wyzlic I. Fish parasites as quality indicators of aquatic environment. Zoologica Poloniae 2009-2010, 55-55(1-4): 59-65. https://doi.org/10.2478/v10049-010-0006-y.

Dzikowski R, Paperna I, Diamant A. Use of fish parasite species richness indices in analyzing anthropogenically impacted coastal marine ecosystems. Helgol Mar Res 2003; 57(3-4): 220-227. http://dx.doi.org/10.1007/s10152-003-0138-2.

Eiras JC, Takemoto RM, Pavanelli GC. Métodos de estudo e técnicas laboratoriais em parasitologia de peixes. Maringá: Eduem; 2000.

El-Robrini M, da Silva MAM, Souza-Filho PWM, El-Robrini MHS, Silva-Júnior OG, França CF. Erosão e progradação do litoral brasileiro/ PARÁ. In: Muehe D, organizador. Erosão e progradação no litoral brasileiro. Brasília: Ministério do Meio Ambiente; 2006. p. 89-130.

Empresa Maranhense de Administração Portuária - EMAP. Estudo de Impacto Ambiental - ElA (Porto do Itaqui) [online]. São Luís: EMAP; 2001 [cited 2020 Dec 29]. Available from: https://www.emap.ma.gov.br/_files/arquivos/RIMA-EMAP-2001.pdf

Empresa Maranhense de Administração Portuária - EMAP. Planejamento Estratégico Ciclo 2018 [online]. São Luís: EMAP; 2018 [cited 2020 Dec 29]. Available from: https://www.emap.ma.gov.br/porto-do-itaqui/planejamento-portuario

Espírito Santo RV, Isaac VJ. Peixes e camarões do estuário do litoral bragantino, Pará, Brasil. Belém: MADAM; 2005.

Gomes RKS, Takiyama LR, Pereira LCC, Silva URL, Ferreira RCM. Social diagnosis and guidelines for coastal management in environmental protection areas of the Amazon Littoral (Amapá, Brazil). J Coast Res 2011; S1(64): 1331-1335.

Justine JL, Beveridge I, Boxshall GA, Bray RA, Miller TL, Moravec F, et al. An annotated list of fish parasites (Isopoda, Copepoda, Monogenea, Digenea, Cestoda, Nematoda) collected from snappers and bream (Lutjanidae, Nemipteridae, Caesionidae) in New Caledonia confirms high parasite biodiversity on coral reef fish. Aquat Biosyst 2012; 8(1): 22. http://dx.doi.org/10.1186/20469063-8-22. PMid:22947621.

Khan RA, Thulin J. Influence of pollution on parasites of aquatic animals. Adv Parasito/ 1991; 30: 201-238. http://dx.doi.org/10.1016/ S0065-308X(08)60309-7. PMid:2069073.

Kritsky DC, Bakenhaster MD, Fajer-Avila EJ, Bullard SA. Rhabdosynochus spp. (Monogenoidea: Diplectanidae) infecting the gill lamellae of Snooks, Centropomus spp. (Perciformes: Centropomidae), in Florida, and redescription of the type species, R. rhabdosynochus. J Parasitol 2010; 96(5): 879-886. http://dx.doi.org/10.1645/GE-2529.1. PMid:20496964.

Lafferty KD. Environmental Parasitology: What can Parasites tell us about Human Impacts on the Environment? Parasitol Today 1997; 13(7): 251-255. http://dx.doi.org/10.1016/S0169-4758(97)01072-7. PMid:15275061.

Le Cren ED. The length-weight relationship and seasonal cycle in gonad weight and condition in the perch (Perca fluviatilis). J Anim Ecol 1951; 20(2): 201-219. http://dx.doi.org/10.2307/1540.

Legendre P, Gallagher ED. Ecologically meaningful transformations for ordination of species data. Oecologia 2001; 129(2): 271280. http://dx.doi.org/10.1007/s004420100716. PMid:28547606.

Lizama MLAP, Takemoto RM, Pavanelli GC. Parasitism influence on the hepato, splenosomatic and weight/length relation and relative condition factor of Prochilodus lineatus (Valenciennes, 1836) (Prochilodontidae) of the Upper Paraná River Floodplain, Brazil. Rev Bras Parasitol Vet 2006; 15(3): 116-122. PMid:16978476.

Mackenzie K. Parasites as pollution indicators in marine ecosystems: a proposed early warning system. Mar Pollut Bull 1999; 38(11): 955-959. http://dx.doi.org/10.1016/S0025-326X(99)00100-9.

Madi RR, Ueta MT. O papel de Ancyrocephalinae (Monogenea: Dactylogyridae), parasito de Geophagus brasiliensis (Pisces: Cichlidae), como indicador ambiental. Rev Bras Parasitol Vet 2009; 18(2): 38-41. http://dx.doi.org/10.4322/rbpv.01802008. PMid:19602315.

Marceniuk AP. Redescrição de Genidens barbus (Lacépède, 1803) e Genidens machadoi (Miranda-Ribeiro, 1918), Bagres Marinhos (Siluriformes, Ariidae) do Atlântico Sul Ocidental. Pap Avulsos Zool 2005; 45(11): 111-125. http://dx.doi.org/10.1590/S003110492005001100001.

Marcogliese DJ. Parasites of the superorganism: are they indicators of ecosystem health? Int J Parasitol 2005; 35(7): 705-716. http://dx.doi.org/10.1016/j.ijpara.2005.01.015. PMid:15925594. 
Monteiro MC, Pereira LCC, Jiménez JA. The trophic status of an amazonian estuary under anthropogenic pressure (Brazil). J Coast Res 2016; 75(sp1): 98-102. http://dx.doi.org/10.2112/SI75-020.1.

Moraes BC, Costa JMN, Costa ACL, Costa MH. Variação espacial e temporal da precipitação no estado do Pará. Acta Amaz 2005; 35(2): 207-214. http://dx.doi.org/10.1590/S0044-59672005000200010.

Moreira LHA, Yamada FH, Ceschini TL, Takemoto RM, Pavanelli GCP. The influence of parasitism on the relative condition factor (kn) of Metynnis lippincottianus (Characidae) from two aquatic environments: the upper Paraná river floodplain and Corvo and Guairacá rivers, Brazil. Acta Sci Bio/ Sci 2010; 32(1): 83-86. http://dx.doi.org/10.4025/actascibiolsci.v32i1.3668.

Nascimento WR Jr, Souza-Filho PWM, Proisy C, Lucas RM, Rosenqvist A. Mapping changes in the largest continuous Amazonian mangrove belt using object-based classification of multisensor satellite imagery. Estuar Coast Shelf Sci 2013; 117: 83-93. http:// dx.doi.org/10.1016/j.ecss.2012.10.005.

Nusch EA. Comparison of different methods for chlorophyll and phaeopigment determination. Arch Hydrobiol 1980; 14 : 4-36.

Palm HW, Kleinertz S, Rückert S. Parasite diversity as an indicator of environmental change? An example from tropical grouper (Epinephelus fuscoguttatus) mariculture in Indonesia. Parasitology 2011; 138(13): 1793-1803. http://dx.doi.org/10.1017/ S0031182011000011. PMid:21320385.

Paranhos R. Alguns métodos para análise da água. Rio de Janeiro: Cadernos Didáticos UFRJ; 1996.

Pereira LCC, Monteiro MC, Guimarães DO, Matos JB, Costa RM. Seasonal effects of wastewater to the water quality of the Caeté river estuary, Brazilian Amazon. An Acad Bras Cienc 2010; 82(2): 467-478. http://dx.doi.org/10.1590/S0001-37652010000200022. PMid:20563427.

Poulin R. Toxic pollution and parasitism in freshwater fish. Parasitol Today 1992; 8(2): 58-61. http://dx.doi.org/10.1016/01694758(92)90090-O. PMid:15463572.

Reef R, Feller IC, Lovelock CE. Nutrition of mangroves. Tree Physiol 2010; 30(9): 1148-1160. http://dx.doi.org/10.1093/treephys/ tpq048. PMid:20566581

Ricker WE. Computation and interpretation of biological statistic of fish populations. Ottawa: Fisheries Research Board of Canada; 1975.

Sasal P, Trouve S, Muller-Graf C, Morand S. Specificity and host predictability: a comparative analysis among Monogenean parasites of fish. J Anim Ecol 1999; 68(3): 437-444. http://dx.doi.org/10.1046/j.1365-2656.1999.00313.x.

Sousa DBP, Almeida ZS, Carvalho-Neta RNF. Biomarcadores histológicos em duas espécies de bagres estuarinos da Costa Maranhense, Brasil. Arq Bras Med Vet Zootec 2013; 65(2): 369-376. http://dx.doi.org/10.1590/S0102-09352013000200011.

Sures B. Environmental parasitology: relevancy of parasites in monitoring environmental pollution. Trends Parasito/ 2004; 20(4): 170-177. http://dx.doi.org/10.1016/j.pt.2004.01.014. PMid:15099556.

Tavares LER, Luque JL. Community ecology of the metazoan parasites of white sea catfish, Netuma barba (Osteichthyes: Ariidae), from the coastal zone of the state of Rio de Janeiro. Braz J Biol 2004; 64(1): 169-176. http://dx.doi.org/10.1590/S151969842004000100019 . PMid:15195376.

Thatcher VE. Patologia de peixes da Amazônia brasileira, 1. Aspectos gerais. Acta Amaz 1981; 11(1): 125-140. http://dx.doi. org/10.1590/1809-43921981111125.

Universidade Federal do Rio de Janeiro - UFRJ. Instituto Aberto Luiz Coimbra de Pós-Graduação e Pesquisa de Engenharia COPPE. Sistema Base de Hidrodinâmica Ambiental - SISBAIA. Baías do Brasil [online]. Rio de Janeiro: UFR]; 2018 [cited 2018 Mar 23]. Available from: http://www.baiasdobrasil.coppe.ufrj.br/\#

Vidal-Martínez VM, Pech D, Sures B, Purucker ST, Poulin R. Can parasites really reveal environmental impact? Trends Parasitol 2009; 26(1): 44-51. http://dx.doi.org/10.1016/j.pt.2009.11.001. PMid:19945346.

Williams HH, Mackenzie K. Marine parasites as pollution indicators: an update. Parasitology 2003;126(126 Suppl): S27-S41. http:// dx.doi.org/10.1017/S0031182003003640. PMid:14667170.

Zambrano JLF, Dezón DE, León YR. Una nueva especie de Monogenea (Dactylogyridae: Calceostomatinae) parásito de Arius herzbergii (Piscis: Ariidae) de la Isla de Margarita, Venezuela. An Inst Biol. Serie Zoología 2004; 75(1): 1-8.

Zargar UR, Chishti MZ, Yousuf AR, Fayaz A. Infection level of monogenean gill parasite, Diplozoon kashmirensis (Monogenea, Polyopisthocotylea) in the Crucian Carp, Carassius carassius from lake ecosystems of an altered water quality: what factors do have an impact on the Diplozoon infection? Vet Parasitol 2012; 189(2-4): 218-226. http://dx.doi.org/10.1016/j.vetpar.2012.04.029. PMid:22608705. 